\title{
Effects of Sludge on the Concentration of Heavy Metals in Soil and Plants in Obunga Slum, Kisumu County, Kenya
}

\author{
Steve Omari Ngodhe* and Edith Achieng Odhiambo \\ Department of Environmental sciences, Rongo University, Kenya
}

Submission: October 15, 2018; Published: October 29, 2018

*Corresponding author: Steve Omari Ngodhe, Department of Environmental sciences, Rongo University, Kenya

\begin{abstract}
The Kisumu Water and Sewerage Company (KIWASCO) releases water with lesser amounts of solid materials removed from liquid sewage (sludge) which is currently being used by small scale farmers for irrigating vegetables such as kales, bananas and spinach for human consumption. There is possible contamination of sludge from industrial effluent, waste material or water containing heavy metals getting into the sewerage system with improper treatment to channel and remove the heavy metals. Contamination of Agricultural soil by heavy metals has become a critical environmental concern due to their potential ecological effects. Harmful metals present in the sludge may thereby lead to contamination of soil and plants. Some of the metals accumulate in the tissues of plants and animals which may end up in the human body and this might therefore cause deleterious health hazards to humans due to bioaccumulation. This paper aims at establishing the levels of some three selected heavy metals (lead, copper, and zinc) both in plants and soil. Sampling was done at various points of the farms surrounding the sewage plant by randomly selecting farm plots around the treatment plant in between January and June 2018. Five different plots were investigated, and the plant analyzed was kales. Soil samples were recovered from the field as a "discrete" sample, mixed, dried, ground and sieved, stored, divided into sub-samples, extracted, measured and analytical data calculated. Similarly, plant samples were obtained, washed, chopped, dried, ground, stored, digested, measured and also calculated. Heavy metal levels were studied by Atomic Absorption Spectrophotometry technique. The results showed that there was no impact of sewage sludge reuse in agriculture on the concentration of heavy metal on soil and plants (kales) in the areas around Obunga slum. The concentrations of the heavy metal of copper, lead and zinc in the soils and plants were below the standards set by KEBS/WHO and FAO. Although heavy metals in the soil and kales analyzed were within the recommended levels and do not pose any immediate risk to human health so far, a regular monitoring program for heavy metals in other common vegetable plants is recommended to minimize the risk of bioaccumulation in human.
\end{abstract}

Keywords: Effects; Sludge; Heavy metals; Concentration; Slum

\section{Background Information}

Although there is no clear definition of what a heavy metal is, density is in most cases taken to be the defining factor. Heavy metals are thus commonly defined as those having a specific density of more than $5 \mathrm{~g} / \mathrm{cm}^{3}$. The main threats to human health from heavy metals are associated with exposure to lead, cadmium, mercury and arsenic [1] Heavy metals have been used in many different areas for thousands of years. Lead has been used for at least 5000 years, early applications including building materials, pigments for glazing ceramics, and pipes for transporting water [2]. In ancient Rome, lead acetate was used to sweeten old wine, and some Romans might have consumed as much as a gram of lead a day. Mercury was allegedly used by the Romans as a salve to alleviate teething pain in infants and was later (from the $1300 \mathrm{~s}$ to the late 1800s) employed as a remedy for syphilis. Claude Monet used cadmium pigments extensively in the mid-1800s, but the scarcity of the metal limited the use in artists' materials until the early 1900s [3]. Although adverse health effects of heavy metals have been known for a long time, exposure to heavy metals continues and is even increasing in some areas. For example, mercury is still used in gold mining in many parts of Latin America. Arsenic is still common in wood preservatives, and tetraethyl lead remains a common additive to petrol, although this use has decreased dramatically in the developed countries. Since the middle of the 19th century, production of heavy metals increased steeply for more than 100 years, with concomitant emissions to the environment [4].

Generation of sewage is increasing due to rapid urbanization. Municipal all over the world are concerned with developing safe and feasible method of disposal [3]. Sewage sludge is a product of sewage treatment plant and result from removal of solids and organic matter from sewage municipal waste and industrial waste water .The application of sewage sludge in agriculture soils has been widespread in many countries. This practice has been shown to improve soil properties e.g. organic matter, nutrients content, porosity, aggregate stability, bulk density and water retention and result to increase plant productivity [2]. All soil contains 
some amount of heavy metals. Some heavy metals such as zinc, copper and chromium are required in minute amount in the body. Exposure to high concentration of the heavy metals in the environment is known to be harmful both in plants and animals [2]. Chronic intake of heavy metal has damage effect on human beings and other animals [5]. For normal soil, the heavy metal content is mainly inherited from parent rocks. The metal present in the soil plant system can easily enter into the food chain. In human, exposure to high levels of heavy metals is known to pose severe health risk such as damage to the organs, cancer and may result in death, and also pause risk for, animals, plant and whole environmental of our modern society [6]. The main concern is the health hazard resulting from possible high levels of heavy metals in food crops. This contamination is as a result of human activities and improper disposal of heavy metal containing materials such as batteries. Previous research has shown the mobility of heavy metals combination in terms of rate of their release and potential negative effect on the soil [7].
Sewage sludge is used in many areas around sewage treatment plants as fertilizer for crops. Research has shown that the use of sewage sludge can result in increased concentration of heavy metals in soil at times to toxic levels. Heavy metals tend to accumulate along the food chain, with possible uptake in plants and livestock. Many people could be at a risk of adverse health effect from consuming vegetables cultivated in soil amended with sludge that is heavy metal contaminated. This can pose a health effect to the economy. It is therefore important to monitor the heavy metals levels in sewage sludge amended soil. The use of sludge from sewage treatment plant in Obunga by small scale farmers may result to accumulation of toxic elements into the soils which can be absorbed by plants. Contamination of Agricultural soil by heavy metals has become a critical Environmental concern due to their potential ecological effects. Such toxic elements are considered as soil pollutants due to their widespread occurrence and their acute and toxic effect on plants grown on such soils.

\section{Materials and Methods}

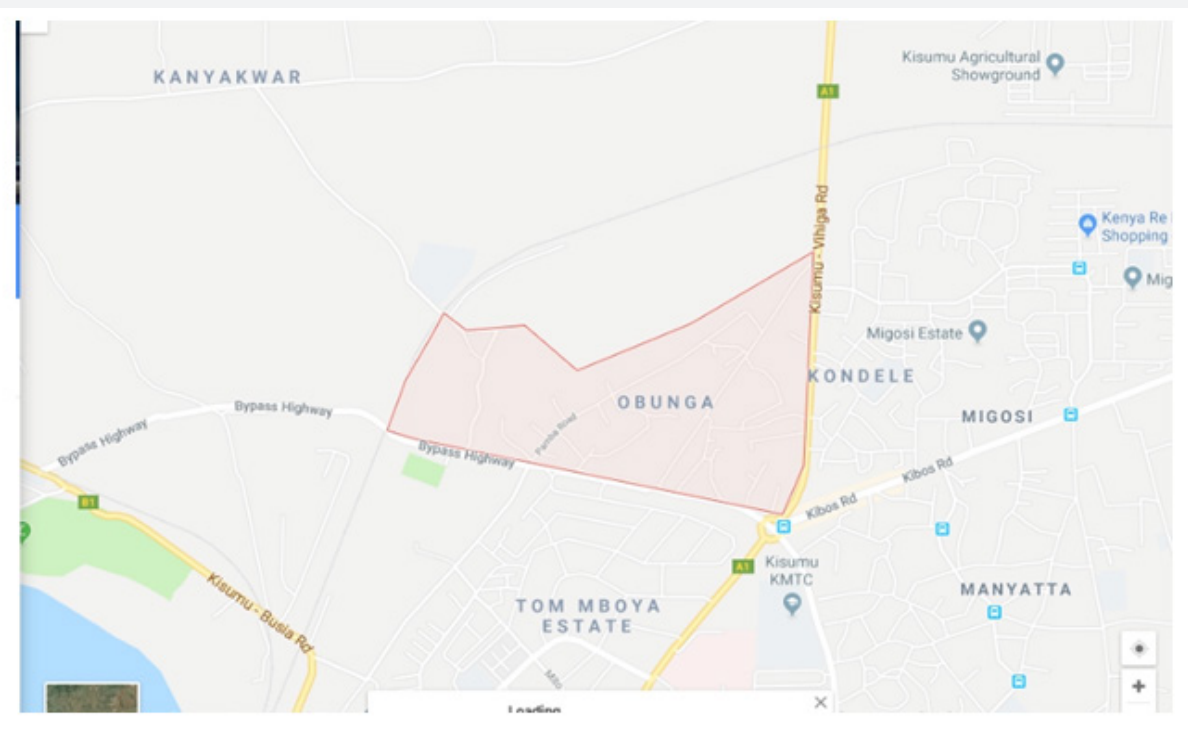

Figure 1: A map showing Obunga area in Kisumu county.

Study samples were taken from areas around KIWASCO treatment plant in Obunga slum located in Kisumu city Kisumu County. The area is situated at an altitude of 1131 meters above the sea level which lies between longitude $34^{\circ} 45^{\prime} \mathrm{E}$ and $34.750^{\circ} \mathrm{E}$ and latitude $0^{\circ} 6^{\prime} \mathrm{S}$ and $0.100^{\circ} \mathrm{S}$ longitude $34^{\circ} 50^{\prime \prime}$ east and $35^{\circ}$ west and latitude $0^{\circ} 03$ (Figure 1) Soil and kale samples were analyzed for a period of 6 months (January- June 2018). Soil and plant samples were collected from five different plots within the areas surrounding KIWASCO sewerage treatment plant. A total of 60 samples were collected from the sites, 30 samples for soil analysis and 30 samples from plant analysis (kales). For plant samples, the leaves were cut using razor blade and placed in paper bag while soil samples were collected from the upper $20 \mathrm{~cm}$ depth of the soil using a stainless-steel scoop. A total of 60 samples for both soil and plant samples were collected from the sites. The samples were then stored in clean polythene bags that had been rinsed with distilled water and then transported to the laboratory for preparation and analysis. Plant samples were washed with tap water and then rinsed with distilled water. The leaves were then chopped into small pieces and oven dried for 48 hours. The samples were then gently crushed into fine powder using dried porcelain mortar and a pestle and then passed through a $2 \mathrm{~mm}$ sieve. They were then placed in clean labeled sample bottle and stored for further analysis. Soil samples were air dried at room temperature for 72 hours. The dry samples were disaggregated using a pestle and a mortar and passed through a $2 \mathrm{~mm}$ sieve. The samples were then oven dried for $2 \mathrm{hrs}$. In every sample, $2.0 \mathrm{~g}$ was accurately weighed using analytical balance and placed into $100 \mathrm{ml}$ measuring cylinder to which $20 \mathrm{ml}$ of tri-acid mixture (Nitric acid, Hydrochloric acid and Sulfuric acid) in a ratio 5:1:1 was added for plant samples while hydrochloric acid and nitric acid in the ratio 3:1 was added for soil samples. Both mixtures were then digested in a hot plate to a transparent liquid digest. The digest was separately cooled, filtered and diluted to $50 \mathrm{ml}$ 
using deionized water for analysis of lead, zinc and copper using Atomic Absorption Spectrometer.

\section{Data Analysis}

The mean, standard errors, line-graphs and bar graphs (classical analysis methods) were carried out to see the variation trend. General linear model analysis of variance was also undertaken for the three heavy metal mean concentrations ( $\mathrm{Zn}$, $\mathrm{Pb}$ and $\mathrm{Cu}$ ) to determine if there is any significant difference in these measurements among the plots, between the months, if there is any interaction between plots and the months sampled (using Minitab 16 software). The mean concentrations of heavy metals were then compared with the recommended WHO, FAO and KEBS standards.

\section{Results}

The mean concentration of heavy metals recorded in both soil and plant samples during the sampling period are recorded. Mean concentration of lead was higher that zinc and copper both in soil and kale samples i.e. $0.41298 \pm 0.102$ and $0.37098 \pm 0.105$ respectively (Table 1). Zinc was higher than copper with a mean concentration of $0.34676 \pm 0.095$ and $0.2302 \pm 0.085$ in soil and kale samples respectively while copper registered the least concentration of $0.1051 \pm 0.002$ and $0.08666 \pm 0.003$ of soil and kale samples respectively (Table 1). Generally, Soil samples recorded higher concentrations of the heavy metals analyzed than kale samples. One-way ANOVA showed a significance difference in the mean concentrations between soil and kale samples during the study period $(\mathrm{p}<0.005)$. The concentration of copper in soil samples was higher plot $3(0.125 \pm 0.005)$ followed by plot $5(0.1165 \pm 0.003)$ while plot 2 recorded the least mean concentration $(0.08 \pm 0.001)$ with plot 1 and 4 with a mean concentration of $0.1095 \pm 0.002$ ) and $0.0945 \pm 0.001$ ) respectively. The analysis of variance showed no significant difference in mean concentration of copper between the soil samples in different plots ( $p>0.005)$. In kale samples plot 1 registered the highest $(0.0995 \pm 0.003)$ and the lowest was recorded in plot $2(0.07 \pm 0.001)$ with plots 3,4 and 5 recording $(0.087 \pm 0.003,0.0853 \pm 0.002,0.0915 \pm 0.001)$ respectively (Figure 2). The analysis of variance still showed no significant difference in mean concentration of copper between the kale samples in different plots $(p>0.005)$. The mean concentration of zinc in the soil samples was higher in plot $5(0.4226 \pm 0.005)$ while plot 4 had the least concentration $(0.2791 \pm 0.001)$. The remaining plots had mean concentrations within the above range. One-way ANOVA showed a significant difference in mean concentration of zinc between the soil samples in different plots $(\mathrm{p}<0.005)$. In kale samples plot 5 still recorded the highest mean concentration of $(0.3622 \pm 0.003)$ with plot 2 having the lowest concentration of $(0.1423 \pm 0.002)$ while the other plots were within the range (Figure 3). ANOVA test showed a significant difference in mean concentration of zinc between the kale samples in different plots $(\mathrm{p}<0.005)$.

Table 1: mean concentration of heavy metals in both soil and kale samples.

\begin{tabular}{|c|c|c|}
\hline \multirow{2}{*}{ Heavy metal } & \multicolumn{2}{|c|}{ Mean Concentrations $(\mathrm{ppm})$} \\
\cline { 2 - 3 } & Soil samples & Kales \\
\hline Copper $(\mathrm{Cu})$ & $0.1051 \pm 0.002$ & $0.08666 \pm 0.003$ \\
\hline Zinc $(\mathrm{Zn})$ & $0.34676 \pm 0.095$ & $0.2302 \pm 0.085$ \\
\hline Lead $(\mathrm{Pb})$ & $0.41298 \pm 0.102$ & $0.37098 \pm 0.105$ \\
\hline
\end{tabular}

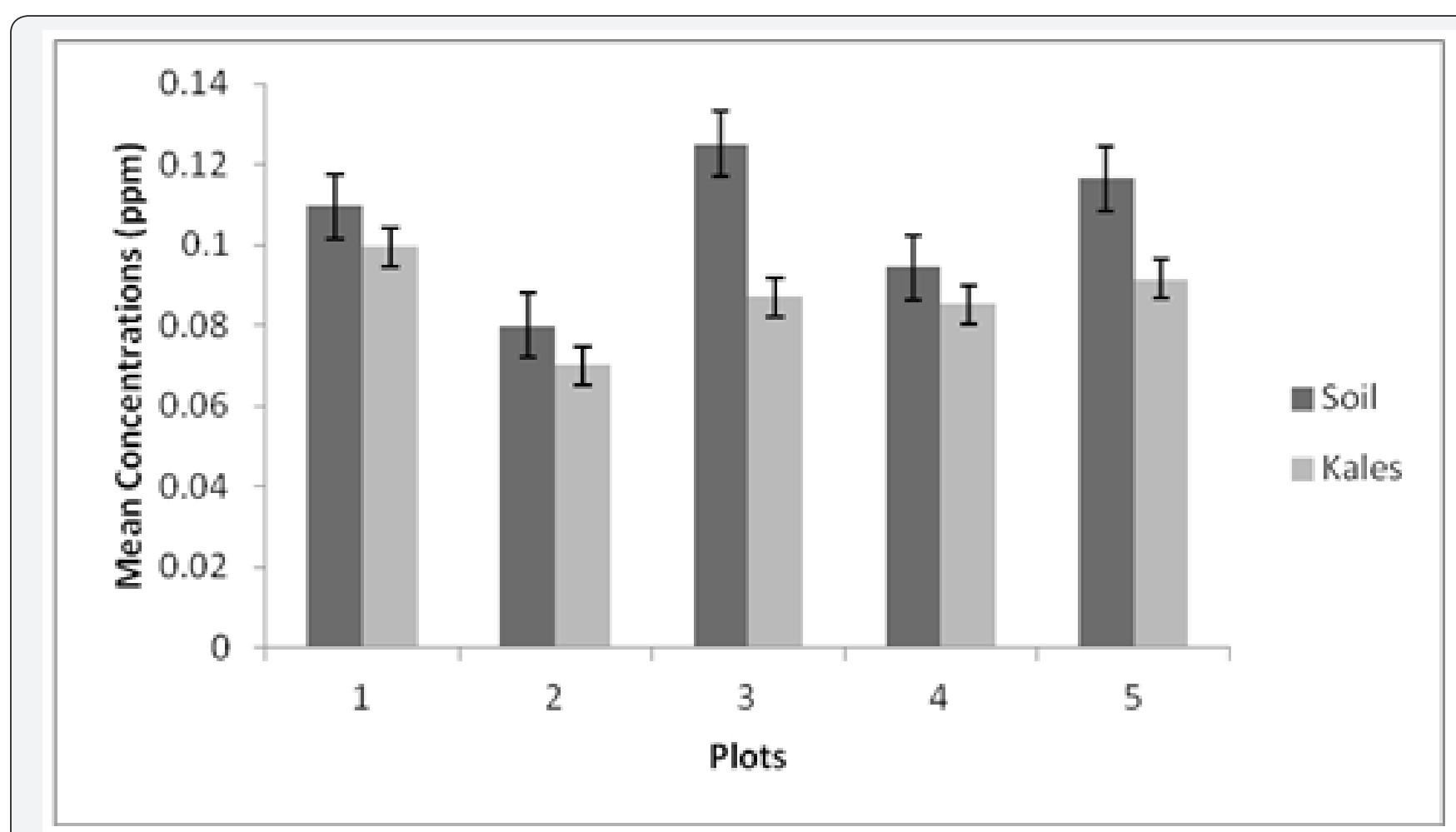

Figure 2: Graph of copper concentration in soil and kale samples during the study period. 

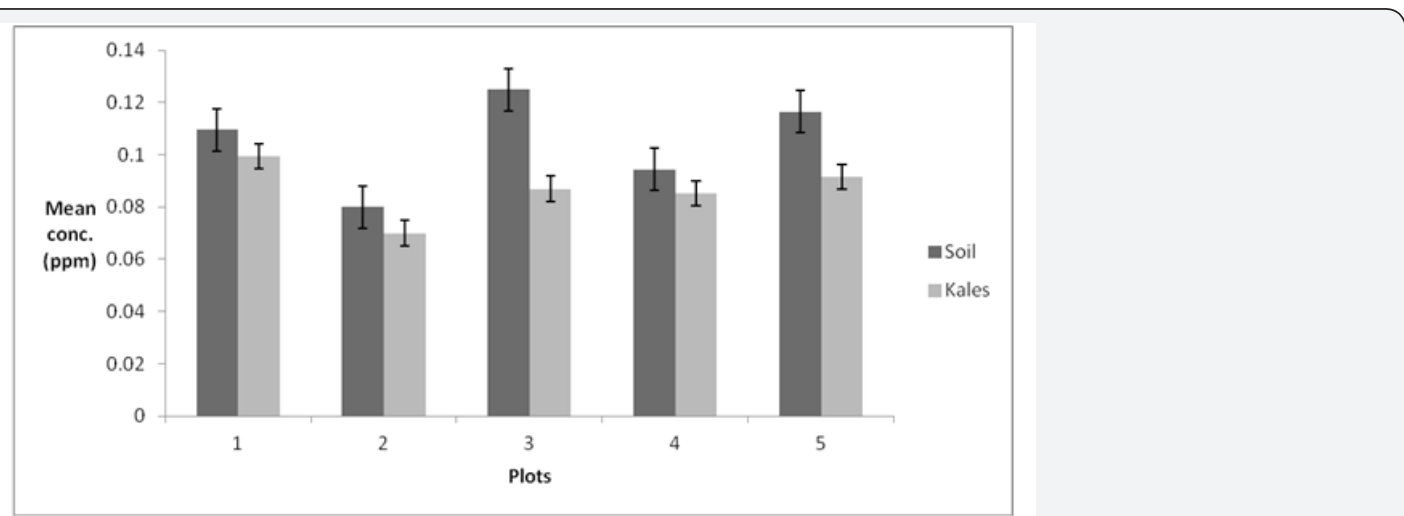

Figure 3: Graph of zinc concentration in soil and kale samples during the study period.

\section{Discussion}

\section{Heavy metals concentrations and soil}

The concentration of the heavy metals in the soil depended on the deposition of the amount of sludge in the soil. Plots exposed to high amounts of sludge had a higher concentration of heavy metals compared to plots exposed to little amount/ application of sludge. This therefore means that the concentration of sludge is directly proportional to that of the heavy metals. Soil contamination by heavy metals is of most important apprehension throughout the industrialized world [8]. Heavy metal pollution not only result in adverse effects on various parameters relating to plant quality and yield but also cause changes in the size, composition and activity of the microbial community and this is why there is differences in mean concentrations in different plots or soil samples. This is in conformity to the study by [1] who studied the effects of heavy metals on soil samples. Therefore, sludge affects the concentrations of heavy metals which are considered as one of the major sources of soil pollution the adverse effects of heavy metals on soil biological and biochemical properties are well documented. The soil properties i.e. organic matter, clay contents and $\mathrm{pH}$ have major influences on the extent of the effects of metals on biological and biochemical properties [9]. Heavy metals indirectly affect soil enzymatic activities by shifting the microbial community which synthesizes enzymes [10]. Heavy metals exhibit toxic effects towards soil biota by affecting key microbial processes and decrease the number and activity of soil microorganisms. According to Chen et al., 2010 the heavy metals caused a decrease in bacterial species richness and a relative increase in soil actinomycetes or even decreases in both the biomass and diversity of the bacterial communities in contaminated soils. Chen et al. [4] also reported that the enzyme activities are influenced in different ways by different metals due to the different chemical affinities of the enzymes in the soil system (Figure 4).

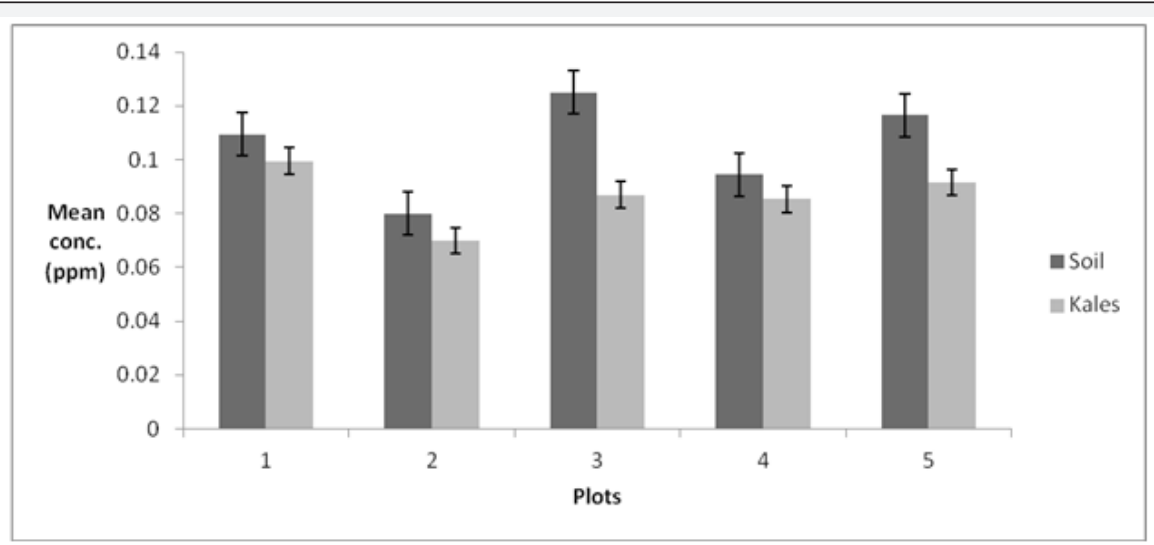

Figure 4: Graph of concentrations of lead in plants and soil.

\section{Heavy metals concentration and vegetation}

There is a difference in the concentrations of heavy metals in different kale samples in this study. The rate of metal uptake by the vegetables (kales) could have been affected by factors such as plant age, plant species, soil $\mathrm{pH}$, nature of soil and climate and this in turn would affect the content of heavy metal recorded. The variations in transfer factor may also have contributed to differences in the metal uptake by different vegetables hence the different metal contents [11]. The use of compost to improve agricultural yield without caring with possible negative effects might be a problem since the waste composts are most applied to improve soils used to grow vegetables. Considering the edible part of the plant in most vegetable species, the risk of transference of heavy metals from soil to humans should be a matter of concern [12]. Uptake of heavy metals by plants and subsequent accumulation along the food chain is a potential threat to animal 
and human health [3]. The absorption by plant roots is one of the main routes of entrance of heavy metals in the food chain [11]. Absorption and accumulation of heavy metals in plant tissue depend upon many factors which include temperature, moisture, organic matter, $\mathrm{pH}$ and nutrient availability.

Heavy metal accumulation in plants might have varied as it depends upon plant the efficiency of different kales in absorbing metals is evaluated by either plant uptake or soil to plant transfer factors of the metals [3]. Elevated $\mathrm{Pb}$ in soils may decrease soil productivity, and a very low $\mathrm{Pb}$ concentration may inhibit some vital plant processes, such as photosynthesis, mitosis and water absorption with toxic symptoms of dark green leaves, wilting of older leaves, stunted foliage and brown short roots [13]. Heavy metals are potentially toxic and phytotoxicity for plants resulting in chlorosis, weak plant growth, yield depression, and may even be accompanied by reduced nutrient uptake, disorders in plant metabolism and reduced ability to fixate molecular nitrogen in leguminous plants [11]. Seed germination was gradually delayed in the presence of increasing concentration of lead $(\mathrm{Pb})$, it may be due to prolong incubation of the seeds that must have resulted in the neutralization of the toxic effects of lead by some mechanisms e. g. leaching, chelation, metal binding or/and accumulation by microorganisms [3].

It can therefore be concluded that there was no negative impact of sewage sludge reuse in agriculture on the concentration of heavy metal on soil and plants (kales) in the areas around Obunga slum since the heavy metal concentrations are still lower than the world recommended levels set by World Health Organization (WHO).

\section{References}

1. Yao H, Xu J, Huang C (2003) Substrate utilization pattern, biomass and activity of microbial communities in a sequence of heavy metalpolluted paddy soils. Geoderma 115(1-2): 139-148.

2. Behbahaninia A, Mirbagheri SA, Khorasani N, Nouri J, Javid AH (2009) Heavy metal contamination of municipal effluent in soil and plants. Journal of Food, Agriculture \& Environment 7(3\&4): 851-856.
3. Speira TW, Kettlesb HA, Percivalc HJ, Parshotam (1999) A Is soil acidification the cause of biochemical responses when soils are amended with heavy metal salts? Soil Biology and Biochemistry 31(14): 1953-1961.

4. Chen YN, Wang L, Zhang WJ (2010) Speciation of Cadmium and Changes in Bacterial Communities in Red Soil Following Application of Cadmium Polluted Compost. Environmental Engineering Science 27(12): 1019-1026.

5. Liu Y, Wei Y, Wang P (2005) Effects of sewage sludge compost application on crops and cropland in a 3 year field study. Chemosphere 59(9): 1257-1265.

6. Farouk M, Farouk A, Umer R (2008) Appraisal of heavy metal contents in different vegetables grown in the vicinity of an industrial area. Pak J Bot 40(5): 2099-2106.

7. Jakubus M, Czeka J (2001) Heavy Metal Speciation in Sewage Sludge. Polish Journal of Environmental Studies 10(4): 245-250.

8. Hinojosa MB, Carreira JA, Ruzz RG, Dick RP (2004) Soil moisture pretreatment effects on enzyme activities as indicators of heavy metal contaminated and reclaimed soils. Soil Biology \& Biochemistry 36: $1559-1568$

9. Duruibe JO, Ogwuegbu MOC, Egwurugwu JN (2007) Heavy metal pollution and human biotoxic effects. International Journal of Physical Sciences 2(5): 112-118.

10. Khan S, Cao Q, Zheng YM, Huang YZ, Zhu YG (2008) Health risks of heavy metals in contaminated soils and food crops irrigated with wastewater in Beijing, China. Environmental Pollution 152(3): 686-692.

11. Wang YP, Shi JY, Wang H, Li Q Chen XC, et al. (2008) The influence of soil heavy metals pollution on soil microbial biomass, enzyme activity, and community composition near a copper smelters. Ecotoxicology and Environmental Safety 67(1): 75-81.

12. Jordao CP, Nascentes CC, Cecon PR, Fontes RLF, Pereira JL (2006) Heavy metal availability in soil amended with composted urban solid wastes. Environmental Monitoring and Assessment 112: 309-326.

13. Karaca A, Cetin SC, Turgay OC, Kizilkaya R (2010) Effects of Heavy Metals on Soil Enzyme Activities. In: I Sherameti and A Varma (Ed) Soil Heavy Metals, Soil Biology, Heidelberg 19: 237-265.

Your next submission with Juniper Publishers will reach you the below assets

- Quality Editorial service

- Swift Peer Review

- Reprints availability

- E-prints Service

- Manuscript Podcast for convenient understanding

- Global attainment for your research

- Manuscript accessibility in different formats

( Pdf, E-pub, Full Text, Audio)

- Unceasing customer service

Track the below URL for one-step submission https://juniperpublishers.com/online-submission.php 